
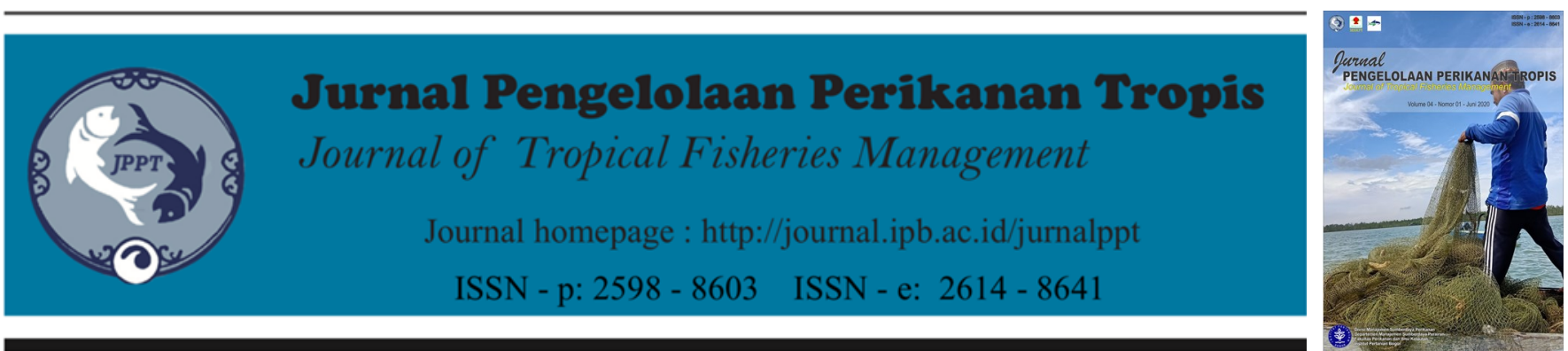

\title{
Komposisi Jenis Plankton Pada Musim Penangkapan Ikan Penja (Gobioidea) di Muara Sungai Mandar
}

\author{
(Composition of Plankton Species in the Fishing Season of Gobioidea at Mandar Estuary)
}

\section{Chichilia Qaila Azzahrah Rahman ${ }^{1 *}$, Mohammad Tauhid Umar ${ }^{2}$, Nita Rukminasari ${ }^{2}$, Shabuddin ${ }^{3}$ \\ ${ }^{1}$ Mahasiswa Program Studi Manajemen Sumberdaya Perairan FIKP Universitas Hasanuddin Makassar \\ ${ }^{2}$ Staf Pengajar Fakultas Ilmu Kelautan dan Perikanan Univeritas Hasanuddin Makassar, Indonesia \\ ${ }^{3}$ Peneliti pada Balai Riset Perikanan Budidaya Perikanan Air Payau Maros Sulawesi Selatan Indonesia}

\begin{tabular}{|c|}
\hline ARTIKEL INFO \\
\hline $\begin{array}{l}\text { Article History } \\
\text { Recevied: } 13 \text { April } 2020 \\
\text { Accepted: } 28 \text { Mei } 2020\end{array}$ \\
\hline $\begin{array}{l}\text { Kata Kunci: } \\
\text { ikan penja, indeks biologi, } \\
\text { kelimpahan, komposisi jenis, } \\
\text { plankton, }\end{array}$ \\
\hline $\begin{array}{l}\text { Keywords: } \\
\text { abundance, ecology index, } \\
\text { composition type, penja fish, } \\
\text { plankton }\end{array}$ \\
\hline
\end{tabular}

\section{Korespondensi Author}

Chichilia Qaila Azzahrah Rahman,

Program Studi Manajemen

Sumberdaya Perairan FIKP

Univeritas Hasanuddin Makassar

Email:

Chichiliaqaila.azzahrah1@gmail.com

\section{ABSTRAK}

Penja adalah ikan endemik di sungai Mandar dan merupakan salah satu spesies ikan pelagis kecil yang telah digunakan oleh para nelayan di Polewali Mandar sejak lama. Ikan penja adalah salah satu organisme air yang memanfaatkan plankton sebagai makanannya. Penelitian ini bertujuan untuk mengetahui komposisi spesies, indeks keanekaragaman, keseragaman dan dominasi plankton pada musim penangkapan ikan di perairan Mandar Kabupaten Polewali Mandar, Provinsi Sulawesi Barat. Penelitian ini dilakukan pada bulan November-Desember 2017. Lokasi pengambilan sampel dilakukan di dua lokasi yang berbeda yaitu di muara dan aliran sungai Mandar, Kabupaten Polewali Mandar, Provinsi Sulawesi Barat. Identifikasi sampel dilakukan di Laboratorium Plankton dan Pakan Alami di Pusat Penelitian Pengembangan Budidaya Air Payau dan Penyuluhan Perikanan (BRPBAP3) Kabupaten Maros. Hasil penelitian ini menunjukkan bahwa kelimpahan plankton tertinggi selama musim penangkapan di perairan muara dan di bulan Desember. Kelas Bacillariophyceae adalah kelas plankton yang paling banyak ditemukan selama penelitian dan ada 37 genus plankton yang terdiri dari 28 gen fitoplankton dan 9 gen zooplankton. Kisaran nilai indeks keanekaragaman selama waktu penangkapan, lokasi pengambilan sampel, bulan penelitian dan waktu pengambilan sampel adalah $1<\mathrm{H}^{\prime}<3$ yang berarti keanekaragaman sedang, nilai indeks keseragaman adalah 0,7-0,9 sehingga indeks keseragaman plankton relatif sama atau sama, dan nilai indeks dominasi menunjukkan bahwa tidak ada genus yang dominan di perairan tersebut.

\begin{abstract}
Penja is an endemic fish in Mandar river and is one of the small pelagic fish species that has been used by fishermen in Polewali Mandar for a long time. Penja fish is one of the water organisms that utilize plankton as its food. This study aims to determine the composition of the plankton species the fishing season in Mandar waters of Polewali Mandar Regency, West Sulawesi Province. This research was conducted in November-December 2017. The sampling location was conducted in two different water locations which are at estuary and flow of Mandar River, Polewali Mandar Regency, West Sulawesi Province. Identification of the samples was done at the Laboratory of Plankton and Natural Feed at the Research Center for Brackishwater Aquaculture Development and Fisheries Extension (BRPBAP3) of Maros Regency. The results of this study indicate that the highest abundance of plankton during fishing season in the estuary waters and in the month of Desember. The Bacillariophyceae class is the most plankton class found during the study and there are 37 genus plankton consisting of 28 genus of phytoplankton and 9 genus of zooplankton. The range of diversity index value during fishing time, sampling location, research month and sampling time is $1<H^{\prime}<3$ which means medium diversity, uniformity index value is 0.7-0.9 so that the plankton uniformity index is relatively the same or equally, and the Domination index value indicates that no domanin genus in the community.
\end{abstract}

\section{PENDAHULUAN}

Ikan penja (Gobioidea sp) merupakan ikan endemik di sungai Mandar dan merupakan salah satu jenis ikan khas pelagis kecil yang dimanfaatkan oleh nelayan Polewali Mandar dengan menggunakan berbagai macam alat 
tangkap seperti Panesser (Jaring seser), Bunde (seser bentuk segi tiga), dan Pasambe (sero). Kegiatan penangkapan yang dilakukan oleh masyarakat nelayan tersebut merupakan mata pencaharian mereka dan telah berkontribusi dalam peningkatan kesejahteraan masyarakat khususnya nelayan yang berdomisili di wilayah pesisir Provinsi Sulawesi Barat tersebut (Sudirman et al. 2016).

Ikan penja umumnya terdapat di daerah pesisir pantai yang berdekatan dengan muara sungai. Kabupaten Polewali Mandar termasuk daerah yang memiliki banyak sungai besar yang bermuara ke laut. Aliran sungai dari hulu atau daratan tentunya membawa unsur hara yang kaya akan nutrien masuk dan sampai ke lautan. Hal ini menjadikan wilayah ini termasuk daerah potensial habitat ikan penja selain itu kondisi ekosistem yang belum tercemar menyebabkan ikan penja menjadikan perairan muara dan sungai sebagai tempat mencari makan berupa plankton dan mikroalga lainnya serta wilayah lintasan migrasinya, sehingga dengan mengetahui keberadaan plankton bisa menjadi petunjuk bagi keberadaan komunitas ikan Penja di sekitar perairan tersebut.

Keberadaan plankton di perairan memiliki pengaruh penting terhadap ketersediaan makanan bagi organisme air. Salah satu organisme air yang memanfaatkan plankton sebagai makanannya adalah ikan penja ini, merupakan ikan kecil atau larva dari ikan payangka (Ophieleotris aporos) sebutan nama ikan yang ada di Danau Tondano yang menyerupai ikan penja. Menurut Soeroto (1988), ikan payangka (Ophieleotris aporos) muda ukuran 10-35 mm (disebut ikan nike) memakan zooplankton dan fitoplankton.

Ikan penja memanfaatkan plankton (zooplankton dan fitoplankton) sebagai makanannya. Jenis zooplankton yang sering ditemukan pada lambungnya, yaitu: Cyclops sp, Nauplius, Keratella sp, Bosmina, Brachionus sp, Ceriodaphnia, dan Polyarthra. Sedangkan untuk jenis fitoplankton yaitu: Oscillatoria sp, Phormidium sp, Nitzschia sp, Cladophora sp, dan Navicula sp (Soeroto 1988).

Mengingat peran dan fungsi plankton dalam rantai makanan dimana ikan-ikan kecil memanfaatkan plankton sebagai makanannya di perairan serta berdasarkan penelitian Soeroto (1988) tentang ikan penja yang memanfaatkan plankton sebagai makanannya maka perlu dilakukan penelitian terhadap kelimpahan dan komposisi jenis plankton pada musim penangkapan ikan penja di perairan tersebut. Hasil penelitian diharapkan bisa menjadi informasi ilmiah tentang komposisi plankton di perairan tersebut yang dapat menjadi petunjuk bagi nelayan tentang keberadaan ikan tersebut sesuai musim kelimpahan plankton.

\section{METODE}

\section{Waktu dan Lokasi Penelitian}

Penelitian ini dilaksanakan pada bulan November-Desember 2017, di muara dan aliran sungai Mandar, Kabupaten Polewali Mandar Provinsi Sulawesi Barat (Gambar 1). Identifikasi sampel dilakukan di Laboratorium Biologi Plankton dan Pakan Alami pada Balai Riset Perikanan Budidaya Air Payau Dan Penyuluhan Perikanan (BRPBAP3) Kabupaten Maros, Sulawesi Selatan.

Penentuan koordinat lokasi sampling menggunakan System Global Positioning System (GPS) merk Garmin Montana 680 serta pengambilan sampel didasarkan pada tempat penangkapan ikan Penja, pada 2 lokasi berbeda, yaitu stasiun I sampai stasiun III di sekitar aliran sungai Mandar yang ditumbuhi pohon nipah, sedangkan stasiun IV sampai stasiun VI adalah di muara/hilir sungai Mandar di desa Para, jarak antar stasiun \pm 50 meter.

\section{Pengambilan sampel di lapangan}

Pengambilan sampel dilakukan pada bulan November sampai Desember 2017 pada 3 waktu berbeda yakni: sebelum musim puncak, saat musim puncak dan setelah musim puncak, dengan interval waktu 3 hari setiap musim penangkapan ikan penja di muara dan aliran Sungai Mandar. Pengambilan sampel plankton pada pagi hari jam 07.00 wita dan siang hari jam 13.00 wita, dengan cara menyaring air sebanyak 100 liter menggunakan plankton net nomor 25. Hasil penyaringan sebanyak $100 \mathrm{ml}$ dimasukkan ke dalam botol sampel kemudian ditetesi larutan lugol sebanyak 4 tetes. Botol sampel tersebut di masukkan ke dalam coolbox yang berisi es batu. Selanjutnya identifikasi sampel plankton dilakukan di Laboratorium Plankton dan Pakan Alami, Balai Riset Perikanan Budidaya Air Payau dan Penyuluhan Perikanan (BRPBAP3) Maros.

\section{Identifikasi dan Perhitungan Kelimpahan Plankton}

Identifikasi sampel plankton diamati di bawah mikroskop monitor Olympus IX71 pembesaran 40x10, menggunakan SRC (Sedgewick Rafter Counter Cell), kemudian individu plankton yang teramati dicocokkan dengan jenis plankton pada buku identifikasi Yamaji (1960) dan Newel dan Newel (1963).

\section{Pengukuran Kualitas Air}

Pengukuran parameter kualitas air secara insitu, yakni: suhu, salinitas, $\mathrm{pH}$, dan oksigen terlarut, sedangkan untuk parameter seperti nitrat, amoniak dan fosfat dianalisis di laboratorium. 


\section{Perhitungan Data}

Untuk menghitung kelimpahan, indeks keanekaragaman, indeks keseragaman, dan indeks dominansi digunakan formula berikut:

\section{Kelimpahan Plankton}

Kelimpahan plankton dihitung menggunakan rumus modifikasi APHA (American Public Health Association) 2010 sebagai berikut:

$$
\mathrm{N}=\frac{a}{b} \times \frac{c}{d} \times \frac{V b}{V s r c} \times \frac{1}{V s}
$$

Dimana $\mathrm{N}$ adalah kelimpahan plankton (plankter/ I), a adalah jumlah kotak SRC, b adalah luas satu lapang pandang $\left(\mathrm{mm}^{2}\right)$, c adalah jumlah Individu yang terlihat, d adalah jumlah kotak yang diamati, $\mathrm{Vb}$ adalah volume air dalam botol sampel $(\mathrm{ml})$, Vsrc adalah volume air dalam SRC (ml), Vs adalah volume air yang disaring di Lapangan (L).

\section{Indeks Keanekaragaman}

Indeks keanekaragaman (H') dihitung dengan menggunakan rumus berikut, (Odum 1971):

$$
H^{\prime}=-\Sigma\left(\frac{n i}{N}\right) \log \left(\frac{n i}{N}\right)
$$

Dimana, H': indeks Keanekaragaman ShannonWiener, $n_{i}$ : jumlah individu spesies ke-i, n: jumlah spesies, N: jumlah total individu.

\section{Indeks Keseragaman}

Indeks keseragaman (E) dihitung dengan menggunakan rumus "Evennes Indeks" (Odum 1971):

$$
E=\frac{H^{\prime}}{H \text { maks }}
$$

Dimana, E: indeks keseragaman, H': Indeks keanekaragaman Shannon-Wiener, Hmax: Log S, S: Jumlah seluruh spesies

Indeks keseragaman berkisar antara 0 sampai 1. Semakin kecil nilai E, semakin kecil pula keseragaman populasi, yang berarti penyebaran jumlah individu setiap spesies tidak sama dan ada kecenderungan terjadi yang didomonasi oleh suatu spesies dari jenis yang ada. Semakin besar nilai $\mathrm{E}$ berarti tidak ada yang mendominasi (Odum 1971).

\section{Indeks Dominansi}

Indeks dominansi (C) dihitung dengan indeks of dominance dari Simpson (Odum 1971), dengan persamaan sebagai berikut:

$$
C=\frac{\sum \mathrm{ni}(\mathrm{ni}-1)}{\mathrm{N}(\mathrm{N}-1)}
$$

Dimana, C: Indeks dominansi Simpson, ni:
Jumlah individu spesies ke-i, n: Jumlah spesies, $\mathrm{N}$ : Jumlah total individu yang teramati

\section{Analisis Data}

Data yang diperoleh selama penelitian diolah menggunakan software PRIMER V.5 (Clarke and Gorley 2001), merupakan salah satu program statistik multivariate analisis untuk mengolah data penelitian yang berhubungan dengan lingkungan. Untuk menganalisis perbedaan struktur komunitas plankton antara musim penangkapan ikan penja, lokasi dan waktu sampling, maka digunakan 3 metode uji dari program PRIMER tersebut, yakni :

\section{nMDS (non Metric Multidimensional Scaling)}

Metode nMDS merupakan output dari suatu program Primer yang menggunakan matriks persamaan untuk melihat bentuk dari suatu struktur sampel (Clark \& Gorley 2001). Plot nMDS didasarkan pada persamaan matriks BrayCurtis yang digunakan untuk menggambarkan komposisi spesies. Jika titik data dalam plot saling berjauhan itu menggambarkan semakin besarnya variasi spesies/data kelompok. Fungsi blog ${ }_{10}(\mathrm{X}+1)$ ialah untuk memberikan arahan persamaan matriks dan persamaan Bray curtis (Clarke 1993).

Stress value yang digunakan untuk mendeteksi akurasi nilai suatu plot yang menggambarkan struktur asli dengan struktur komposisi sampel yang didapat, yaitu:

stress value $<0,05$ merupakan plot yang sempurna, dengan kemungkinan tidak ada kesalahan dalam menginterpretasikannya.

Stress value $<0,15$ menggambarkan plot yang cukup akurat dengan tingkat kesalahan interpretasi rendah.

Stress value $<0,2$ menggambarkan plot kurang baik untuk digunakan

Stress value $>0,2$ menggambarkan sangat besar kemungkinan terjadinya kesalahan menginterpretasikannya.

\section{ANOSIM (Analysis of Similarity)}

Analysis of similarity (ANOSIM) merupakan analisis secara statistic untuk mengetahui ada tidaknya perbedan struktur komunitas antara kondisi atau parameter yang di uji. Berdasarkan ANOSIM ini akan diketahui tinggi rendahnya variasi sampel/parameter yang diukur yaitu dengan melihat nilai Global R. Semakin besar nilai Global maka semakin kecil variasi sampel. Untuk melihat ada tidaknya perbedaan dari struktur spesies di setiap lokasi yang diuji, dapat dilihat dari nilai statistiknya $\mathrm{P}<0,05$ (Clarke and Ainsworth 1993; Clarke 1993).

\section{SIMPER (Similarity Of Percentage)}

Metode similarity of percentage (SIMPER) merupakan suatu output dari program primer dominan di lokasi yang berbeda, untuk 
mengetahui perbedaan spesies diantara faktor uji dan spesies yang menjadi pembeda (Clark \& Gorley 2001).

\section{HASIL DAN PEMBAHASAN}

\section{Hasil}

\section{Komposisi Jenis}

Hasil penelitian menunjukkan bahwa total genus plankton yang ditemukan adalah di muara terdapat 32 kelas (24 kelas fitoplankton dan 8 kelas zooplankton) sedangakan di aliran sungai 29 klas (23 kelas fitoplankton dan 6 kelas zooplankton) di muara pada Tabel 1.

\section{Total Kelas Plankton}

Komposisi plankton berdasarkan kelas selama penelitian dapat di lihat pada Gambar 2 dan 3. Pada Gambar 2 dan 3 menunjukkan bahwa terdapat 4 kelas fitoplankton dan 4 kelas

Tabel 1 Komposisi jenis plankton di muara dan aliran sungai Mandar

\begin{tabular}{|c|c|c|c|}
\hline No & Kelompok plankton & Aliran sungai & Muara \\
\hline 1 & \multirow{37}{*}{ Fitoplankton } & Amphora & Amphora \\
\hline 2 & & Asterionella & Asterionella \\
\hline 3 & & Bachillaria & Bachillaria \\
\hline 4 & & Tak teridentifikasi & Bidhulpia \\
\hline 5 & & Centropyxis & Centropyxis \\
\hline 6 & & Ceratium & Ceratium \\
\hline 7 & & Chaetoseros & Chaetoseros \\
\hline 8 & & Tak teridentifikasi & Climacosphenia \\
\hline 9 & & Coconeis & Coconeis \\
\hline 10 & & Coscinodiscus & Coscinodiscus \\
\hline 11 & & Cromoonas & Cromoonas \\
\hline 12 & & Diploneis & Diploneis \\
\hline 13 & & Favella & Favella \\
\hline 14 & & Fragilaria & Fragilaria \\
\hline 15 & & Melosira & Melosira \\
\hline 16 & & Navicula & Navicula \\
\hline 17 & & Nitzchia & Nitzchia \\
\hline z18 & & Oschillatoria & Oscillatoria \\
\hline 19 & & Paravafella & Tak teridentifikasi \\
\hline 20 & & Tak teridentifikasi & Pleurosigma \\
\hline 21 & & Protoperidinium & Protoperidinium \\
\hline 22 & & Pseudonitzchia & Pseudonitzchia \\
\hline 23 & & Polykrikos & Tak teridentifikasi \\
\hline 24 & & Rhizosolenia & Rhizosolenia \\
\hline 25 & & Tak teridentifikasi & Spirullina \\
\hline 26 & & Tak teridentifikasi & Streptotheca \\
\hline 27 & & Thallasionema & Tak teridentifikasi \\
\hline 28 & & Thallasiosira & Tak teridentifikasi \\
\hline 29 & & Acartia & Acartia \\
\hline 30 & & Aphocyclopas & Aphocyclopas \\
\hline 31 & & Brachionus & Brachionus \\
\hline 32 & & Copepoda & Copepoda \\
\hline 33 & & Tak teridentifikasi & Naupli \\
\hline 34 & & Oithona & Oithona \\
\hline 35 & & Tak teridentifikasi & Polychaeta \\
\hline 36 & & Tintinopsis & Tak teridentifikasi \\
\hline 37 & & Tak teridentifikasi & Tortanus \\
\hline
\end{tabular}

Keterangan :

kolom biru menunjukkan genus plankton yang tidak terdapat di sungai

kolom kuning menunjukkan genus plankton yang tidak terdapat di muara 


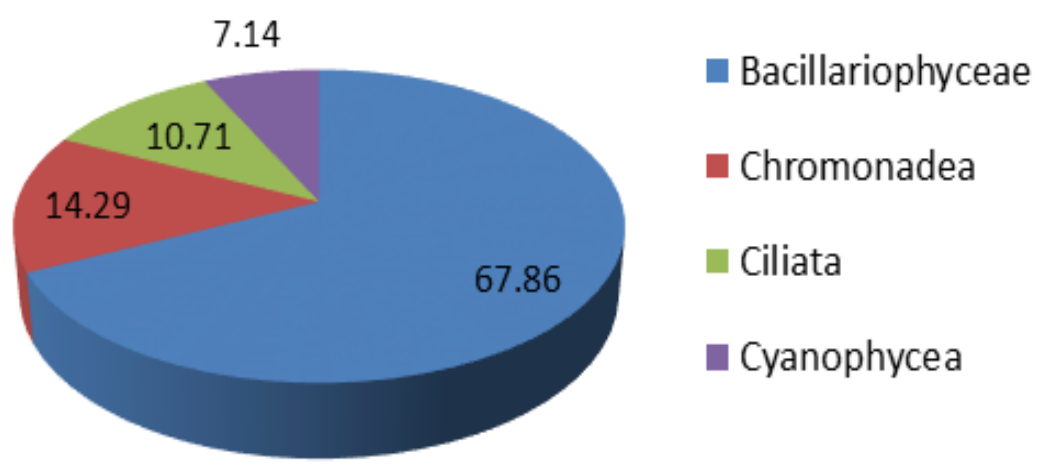

Gambar 2 Komposisi fitoplankton berdasarkan kelas selama musim penangkapan ikan penja di lokasi penelitian

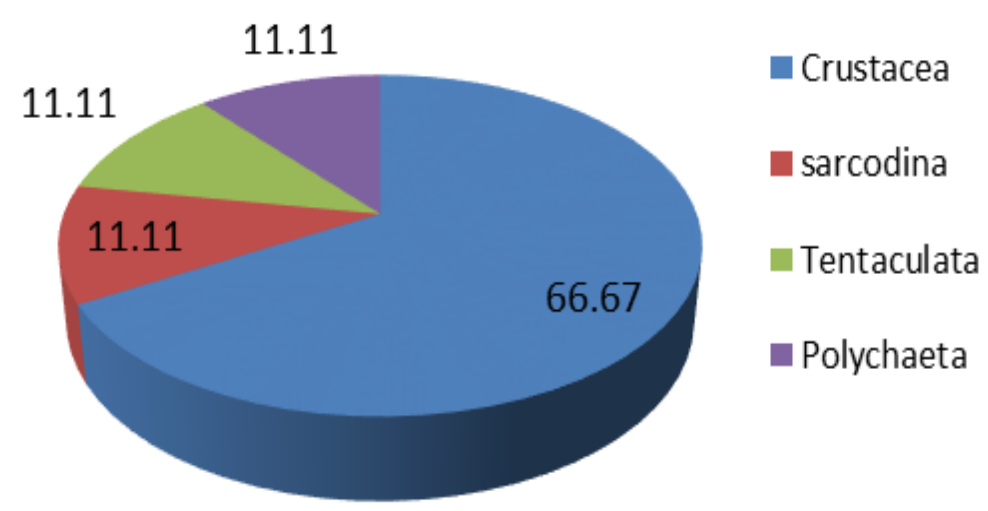

Gambar 3 Komposisi zooplankton berdasarkan kelas selama musim penangkapan ikan penja di lokasi penelitian

zooplankton. Dari Kelas Bacillariophyceae genus yang ditemukan dalah Amphora, Asterionella, Diploneis, Fragillaria, Melosira, Navicula, Nitzchia, Pleurosigma, Pseudonitzchia, Rhizosolenia, Streptotheca, Thallasionema, dan Thallasiosira. Kelas Cromonadea yaitu Ceratium, Cromonas, Protoperidinium, dan Polykrikos. Kelas Ciliata yaitu Favella, Paravella dan Tintinopsis. Kelas Crustacea yaitu Acartia, Apocyclopas, Copepoda, Naupli, Oithona, dan Tortanus. Kelas Cyanophycea yaitu Oschillatoria dan Spirullina. Kemudian untuk Kelas Tentaculata yaitu Brachiounus, kelas Sarcodina yaitu Centropyxis dan kelas Polyhaeta yaitu Polychaeta.

Keberadaan fitoplankton yag dominan dari Kelas Bacillariophyceae, hal ini diduga di sebabkan karena plankton tersebut dapat menyesuaikan diri dengan kondisi salinitas di perairan, yaitu berkisar antara 10-28\%. Menurut Sachlan (1972), fitoplankton yang hidup pada kisaran salinitas di atas 20\% sebagian besar merupakan plankton dari kelompok Bacillariophycheae, selanjutnya Arsil (1999), menyatakan bahwa Bacillariophycheae lebih mudah beradaptasi dengan lingkungan dan merupakan kelompok fitoplankton yang disenangi oleh ikan dan larva udang.

\section{Perbandingan Kelimpahan Plankton}

Perbandingan kelimpahan berdasarkan waktu penangkapan ikan penja dengan lokasi pengambilan sampling, waktu penelitan, dan waktu sampling dapat dilihat Gambar 4-6.

Berdasarkan Gambar 4 dapat dilihat perbedaan kelimpahan plankton yang signifikan. Kelimpahan relatif tinggi pada saat musim penangkapan ikan penja yaitu $822 \mathrm{ind} / \mathrm{L}$ di muara dan 313 ind/L di sungai., sedangkan kelimpahan relatif rendah pada waktu sesudah musim penangkapan ikan penja yaitu $351 \mathrm{ind} / \mathrm{L}$ di Muara dan $180 \mathrm{ind} / \mathrm{L}$ di Sungai. Pada waktu sebelum musim penangkapan ikan penja, di Muara kelimpahan rata-rata plankton yaitu $655 \mathrm{ind} / \mathrm{L}$, dan di sungai kelimpahan rata - rata plankton yaitu $330 \mathrm{ind} / \mathrm{L}$.

Kelimpahan plankton setelah musim penangkapan ikan penja relatif rendah, hal ini dikarena pada waktu tersebut plankton telah dimakan oleh ikan penja dan organism perairan lain. Menurut Soeroto (1988), ikan payangka muda ukuran 10-35 mm (di sebut ikan nike) memakan zooplankton dan fitoplankton. 


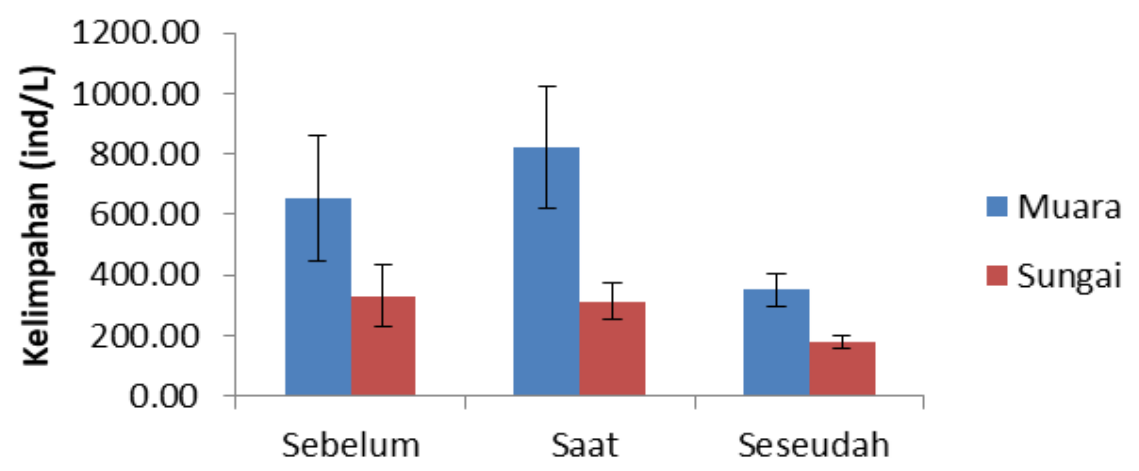

Gambar 4 Histogram perbedaan kelimpahan antar waktu musim penangkapan ikan penja dan lokasi pengambilan sampel $(\mathrm{X} \pm \mathrm{SE}, \mathrm{N}=3)$

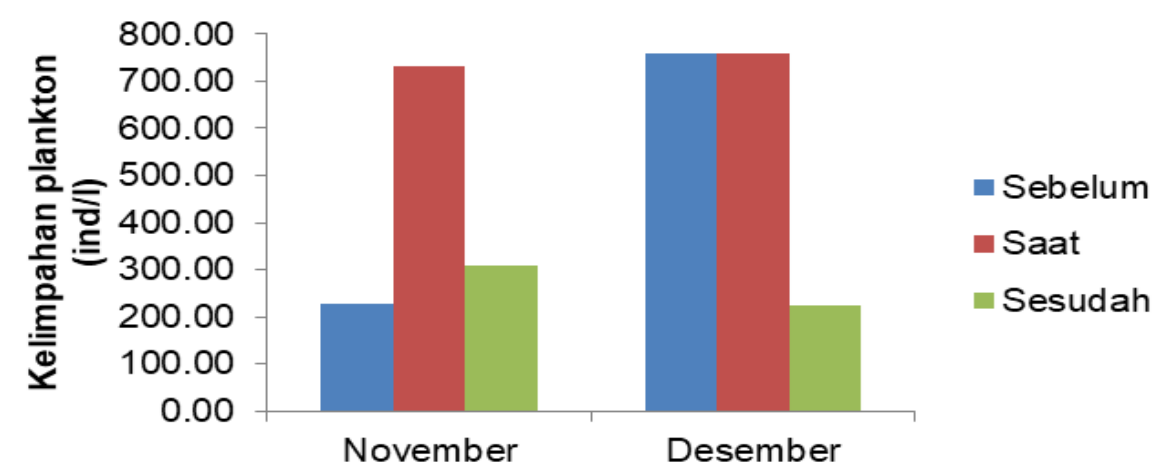

Gambar 5 Histogram perbedaan kelimpahan plankton pada bulan penelitian dan antar waktu penangkapan ikan penja $(\mathrm{X} \pm \mathrm{SE}, \mathrm{N}=3)$

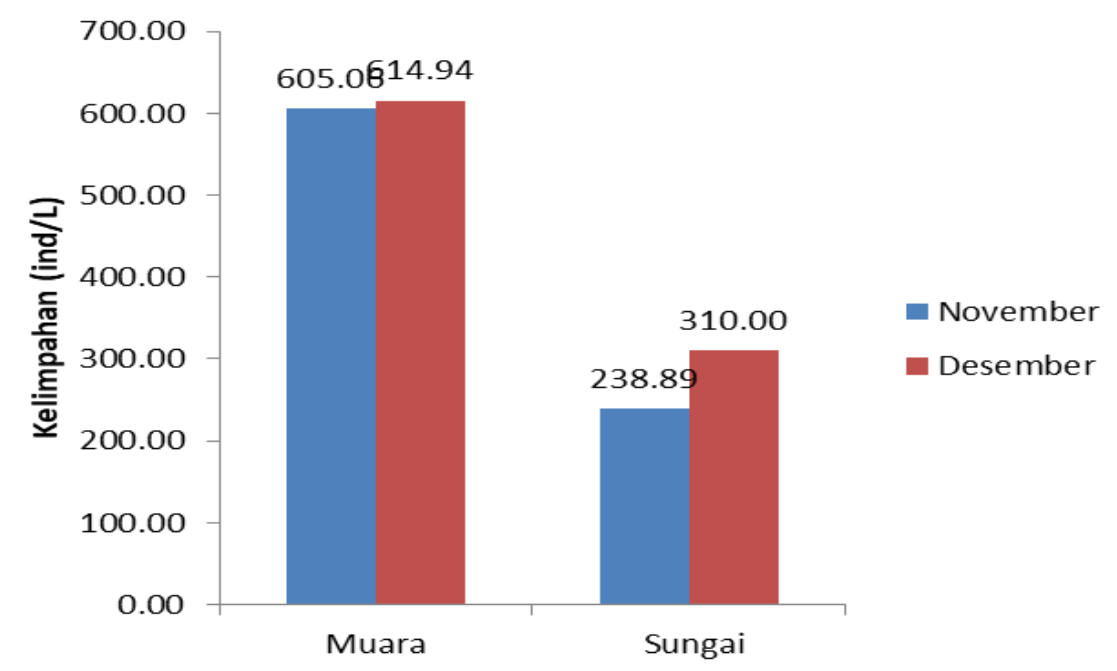

Gambar 6 Histogram perbedaan kelimpahan antara lokasi pengambilan sampel dengan bulan penelitian $(\mathrm{X} \pm \mathrm{SE}, \mathrm{N}=2)$

Sedangkan pada musim penangkapan ikan penja nilai kelimpahannya relatif tinggi dibandingkan sebelum dan setelah musim penangkapan ikan penja. Hal ini dikarena kelimpahan plankton sebagai tanda atau ciri bahwa ikan penja akan muncul karena plankton merupakan makanan bagi ikan penja, sesuai komunikasi personal dengan nelayan setempat, bahwa salah satu ciri-ciri ikan penja akan muncul, di permukaan air akan tampak berwarna merah atau kecoklatan saat terjadi hujan.

Gambar 5 memperlihatkan kelimpahan plankton pada bulan November dan Desember pada waktu musim penangkap ikan penja. Kelimpahan plankton relatif tinggi di dapatkan pada bulan Desember di waktu musim penangkapan ikan penja, dengan nilai pada waktu sebelum musim penangkapan ikan penja yaitu $759 \mathrm{ind} / \mathrm{L}$, waktu saat musim penangkapan ikan 
penja yaitu 759 ind/L dan waktu sesudah musimpenangkapan ikan penja yaitu 224 ind/L. sedangkan pada bulan November kelimpahan planton relatif rendah pada waktu musim penangkapan ikan penja, dengan nilai pada waktu sebelum musim penangkapan yaitu 226 ind/L, waktu saat musim penangkapan ikan yaitu 731 ind/L dan waktu sesudah musim penangkapan ikan yaitu $307 \mathrm{ind} / \mathrm{L}$.

Berdasarkan Gambar 5 kelimpahan plankton relatif tinggi pada Desember di waktu musim penangkapan ikan penja, hal ini dimungkinkan dengan kondisi musim hujan yang membawa nutrien dari aliran sungai sehingga mendukung kemelimpahan plankton yang menggunakan nutrien sebagai faktor utama pertumbuhan fitoplankton, sebagaimana yang direkomendasikan oleh Dirjen Perikanan (1985) bahwa kandungan nitrat yang dibutuhkan untuk perkembangan alga dan fitoplankton berkisar antara 0,3-17 $\mathrm{mg} / \mathrm{L}$. Suatu perairan dapat dikatakan subur apabila kadar fosfatnya berkisar antara 0,060-10 ppm (Effendi 2003). Hasil pengukuran fosfat di muara dan aliran sungai Mandar ppm berkisar 0,1-0,3 ppm dan kandungan nitrat yang terukur berkisar 0,1-1 ppm, kandungan nutrient tersebut mendukung pertumbuhan fitoplankton.

Berdasarkan diagram pada Gambar 6 dapat dilihat kelimpahan plankton yang ditemukan di setiap lokasi pengambilan sampel pada bulan sampling yang berbeda. kelimpahan relatif tinggi di muara yaitu 605 ind/L pada bulan November dan 614 ind/L pada bulan Desember. Sedangkan kelimpahan relatif rendah di daerah sungai yaitu 238 ind/L pada bulan November dan 310 ind/L pada bulan Desember.

Berdasarkan Gambar 6 menunjukkan hasil kelimpahan plankton relatif tinggi di lokasi muara karena adanya konsentrasi nutrien yang lebih tinggi di muara, secara umum kelimpahan plankton lebih tinggi di muara baik bulan November maupun bulan Desember, hal ini dikarenakan di muara unsur haranya lebih tinggi di bandingkan di sungai. Letak Muara yang berdekatan dengan laut sehingga kondisi muara sangat mendukung kehidupan plankton. Berdasarkan penelitian Andriani et al. (2015) bahwa fitoplankton dengan kelimpahan yang tinggi umumnya di temukan di lokasi dekat dengan muara sungai. Hal ini ini disebabkan daerah muara sungai mempunyai unsur hara yang cukup. Unsur hara tersebut berasal dari daerah yang dialirkan dari sungai menuju laut (Radiarta 2012).

\section{Indeks Keanekaragaman, Indeks Keseragaman dan Indeks Dominansi Simpson}

Nilai indeks keanekaragaman, indeks keseragaman dan indeks dominansi menggambarkan nilai keberagaman, keseragaman dan dominansi plankton yang ditemukan selama penelitian di aliran dan muara sungai Mandar, tertera pada Gambar 7, Gambar 8 dan Gambar 9.

Nilai indeks keanekaragaman plankton menggambarkan nilai keberagaman plankton di lokasi sampling. Nilai indeks keanekaragaman rata-rata sebelum waktu penangkapan ikan penja adalah 1,651, nilai indeks keanekaragaman ratarata pada saat musim penangkapan adalah 1,767 dan nilai indeks keanekaragaman rata-rata sesudah musim penangkapan adalah 1,723. Kemudian di lokasi sampling nilai indeks keanekaragaman rata-rata di muara adalah 1,968 dan di badan sungai 1,458. Nilai indeks kenakearagaman di muara lebih tinggi dibandingkan dengan aliran sungai, hal ini terjadi karena keberadaan plankton dipengaruhi oleh kandungan nutrient yang tinggi di muara sehingga kemunculan berbagai jenis plankton lebih banyak di muara dibandingkan di aliran sungai. Pada bulan November nilai keanekaragamannya lebih tinggi yakni 1,760 dibanding bulan Desember adalah 1,668, tapi nilai kemelimpahan lebih tinggi di bulan Desember karena merupakan puncak musim hujan dimana aliran air sungai yang mengarah ke muara membawa nutrien yang tinggi sehingga memperkaya kesuburan saat sampling pada bulan tersebut.

Kisaran nilai indeks keanekaragaman pada waktu penangkapan ikan penja, lokasi sampling, bulan penelitian dan waktu sampling adalah $1<\mathrm{H}^{\prime}<3$, dengan demikian keanekaragaman planktonnya adalah komunitas dengan keanekaragaman sedang. Sesuai dengan pendapat Masson (1981) tentang kisaran nilai indeks keanekaragaman, bahwa nilai $1<\mathrm{H}^{\prime}<3$ menunjukkan komunitas dengan keanekaragaman sedang.

Berdasarkan Gambar 7 ditemukan nilai indeks keanekaragaman tertinggi pada waktu penangkapan ikan penja yaitu pada waktu saat penangkapan ikan penja dengan nilai indeks keanekaragaman rata-rata 1,767 . Kemudian nilai indeks tertinggi di lokasi sampling yaitu di muara dengan nilai indeks keanekaragaman 1,968. Nilai keanekaragaman tinggi saat musim tangkapan, hal itulah yang mendukung keberadaan ikan Penja yang cenderung mengikuti kemelinpahan plankton ddari berbagai jenis plankton yang ada karena merupakan pakan alami bagi ikan-ikan tersebut.

Pada waktu penangkapan ikan penja, nilai indeks keseragaman rata-rata pada waktu sebelum penangkapan adalah 0,813 , nilai indeks keseragaman rata-rata pada saat musim penangkapan adalah 0,801 dan nilai indeks keseragaman rata-rata pada waktu sesudah penangkapan adalah 0,848. Kemudian di lokasi, sampling nilai indeks keseragaman rata-rata di 


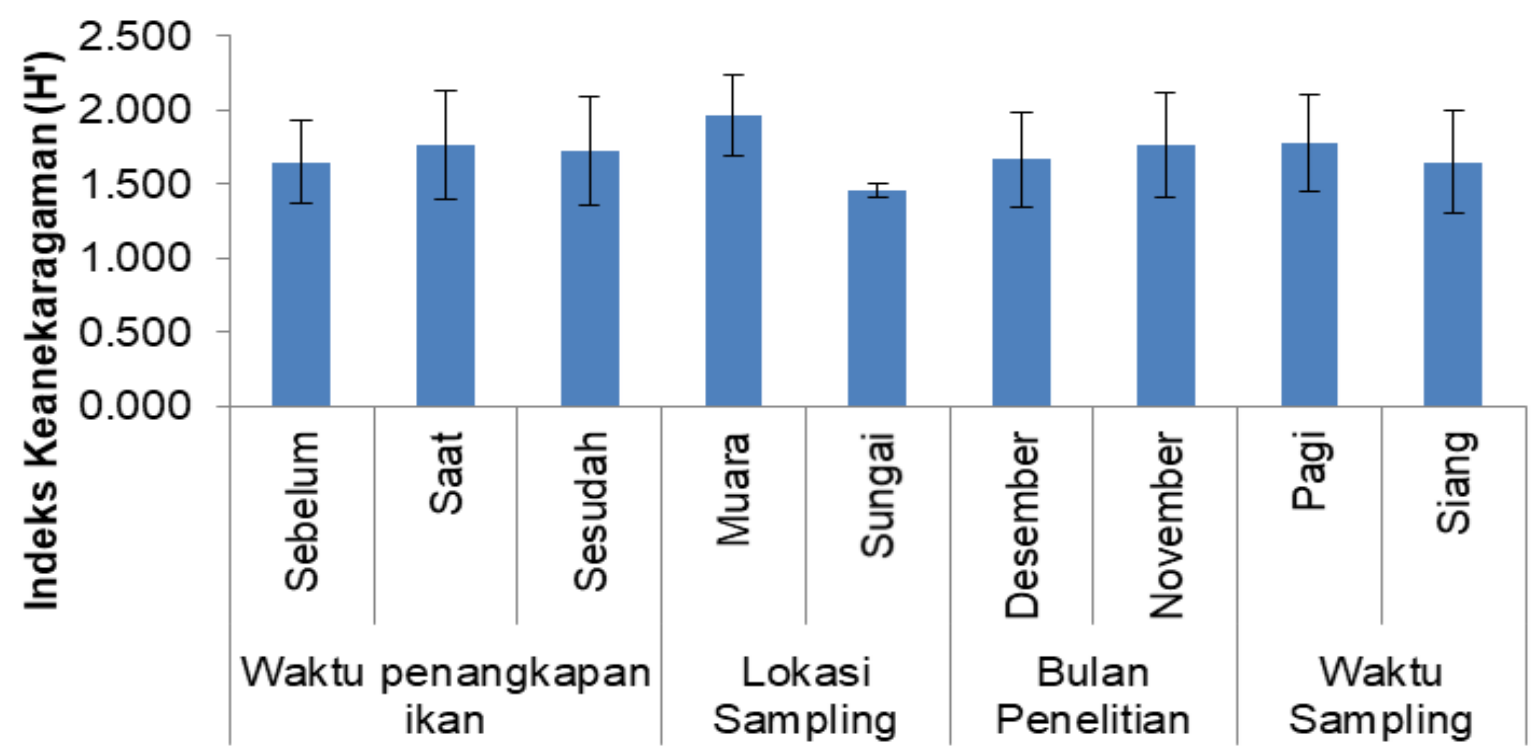

Gambar 7 Histogram indeks keanekaragaman di Muara dan badan Sungai Mandar pada waktu penangkapan ikan penja, lokasi sampling, bulan sampling, dan waktu sampling

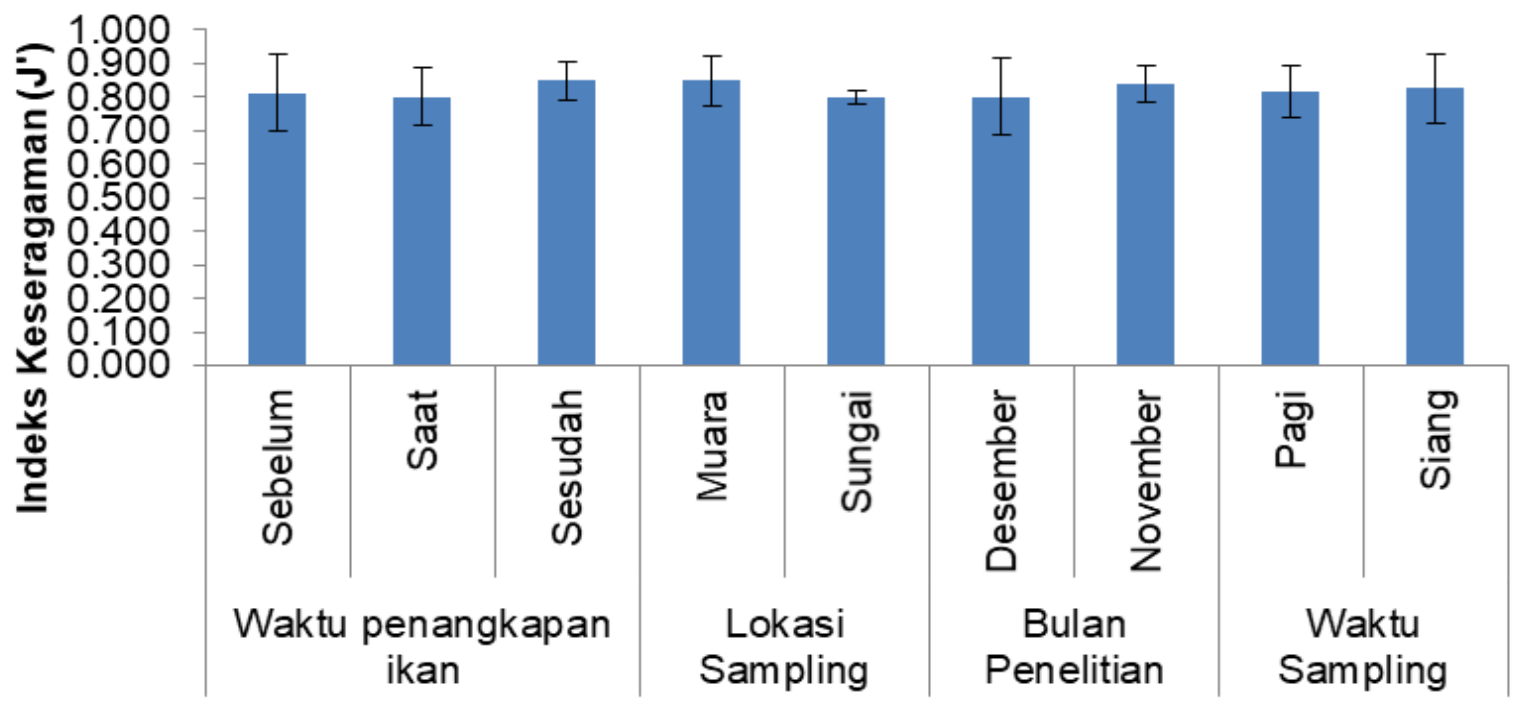

Gambar 8 Histogram indeks keseragaman di muara dan aliran sungai Mandar pada waktu penangkapan ikan penja, lokasi sampling, bulan sampling, dan waktu sampling

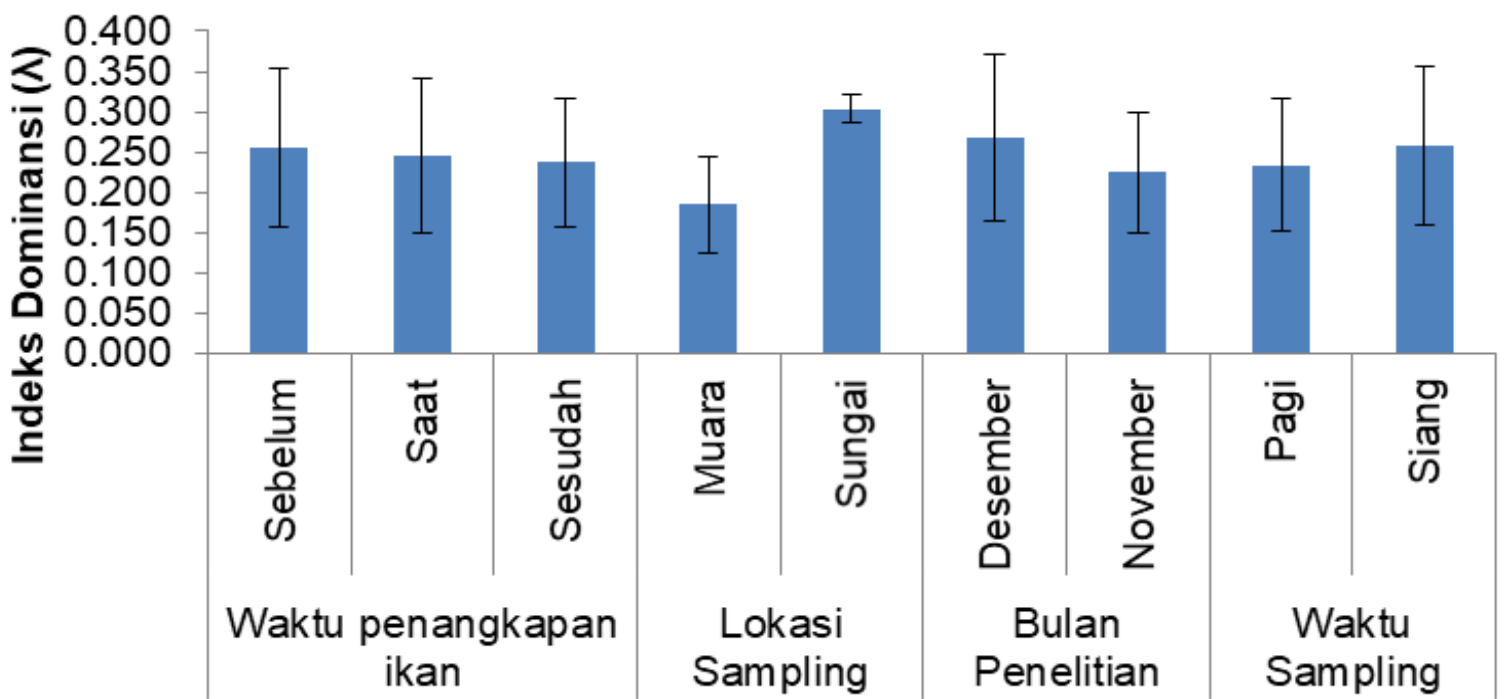

Gambar 9 Histogram indeks dominansi di perairan muara dan badan sungai Mandar pada waktu penangkapan ikan penja, lokasi sampling, bulan sampling, dan waktu sampling 
Muara adalah 0,849 dan di badan sungai 0,800. Pada bulan penelitian nilai indeks keseragaman rata-rata pada bulan November adalah 0,839 dan pada bulan Desember adalah 0,802. Sementara pada waktu sampling, nilai indeks keseragaman rata-rata di pagi hari adalah 0,816 dan di siang hari 0,825 .

Kisaran nilai indeks keseragaman pada waktu penangkapan ikan penja, lokasi sampling, bulan penelitian dan waktu sampling adalah 0,7-0,9 sehingga indeks keseragaman planktonnya adalah relatif sama atau merata, yaitu mendekati 1 dan menunjukkan jumlah individu tiap spesies sama atau merata. Sesuai dengan teori bahwa semakin kecil nilai Indeks Keseragaman menunjukkan penyebaran jumlah individu setiap spesies atau genus tidak sama, dan menunjukkan kecenderungan dominasi salah satu pada populasi tersebut. Sebaliknya, semakin besar indeks keseragamannya jumlah individu tiap spesies sama atau merata (Hasanah et al. 2014).

Berdasarkan Gambar 8 Nilai indeks keseragaman tertinggi pada waktu penangkapan ikan penja yaitu pada waktu sesudah penangkapan ikan penja dengan nilai indeks keseragaman rata-rata 0,848 . Kemudian nilai indeks tertinggi di lokasi sampling yaitu di Muara dengan nilai indeks keseragaman 0,849. Sementara nilai indeks keseragaman tertinggi pada bulan penelitian yaitu pada bulan November dengan nilai keseragaman 0,839 . Dan nilai indeks tertinggi pada waktu sampling yaitu pada siang hari dengan nilai keseragaman 0,825.

Pada waktu penangkapan ikan, nilai indeks dominansi rata-rata pada waktu sebelum penangkapan adalah 0,255, nilai indeks dominansi rata-rata pada saat musim penangkapan adalah 0,245 dan nilai indeks dominansirata-rata pada waktu sesudah penangkapan adalah 0,237. Kemudian di lokasi, sampling nilai indeks dominansi rata-rata di muara adalah 0,184 dan di badan sungai 0,304. Pada bulan penelitian nilai indeks dominansi ratarata pada bulan November adalah 0,224 dan padabulan Desember adalah 0,267. Sementara pada waktu sampling, nilai indeks dominansi rata -rata di pagi hari adalah 0,234 dan di siang hari 0,258 .

Kisaran nilai indeks dominasi pada waktu penangkapan ikan penja, lokasi sampling, bulan penelitian dan waktu sampling menunjukkan tidak ada genus domanin dalam komunitas. Indeks dominansi berkisar antara 0 sampai 1, dimana semakin kecil nilai indeks dominansi maka menunjukan bahwa tidak ada spesies yang mendominsi sebaliknya semakin besar dominansi maka menunjukkan ada spesies tertentu (Odum 1993).

Berdasarkan Gambar 9 Nilai indeks dominansi tertinggi pada waktu penangkapan ikan penja yaitu pada waktu sebelum penangkapan ikan penja dengan nilai indeks dominansi rata-rata 0,255 . Kemudian nilai indeks tertinggi di lokasi sampling yaitu di badan sungai dengan nilai indeks dominansi 0,304. Sementara nilai indeks dominansi tertinggi pada bulan penelitian yaitu pada bulan Desember dengan nilai 0,267. Dan nilai indeks dominansi tertinggi pada waktu sampling yaitu pada siang hari dengan nilai 0,258 , ini menunjukkan bahwa kondisi perairan tersebut termasuk kategori baik bagi keberadaan organisme mikroskopik plankton.

\section{Uji Perbedaan Komposisi Penyusun Struktur Komunitas}

Perbedaan struktur komunitas antar waktu penangkapan ikan penja, lokasi sampling, bulan penelitian, dan waktu sampling dengan menggunakan metode uji dari program PRIMER dengan nMDS (non Metric Multidimensional Scaling).

\section{non Metric Multidimensional Scaling (nMDS) Waktu Musim Penangkapan Ikan Penja}

Plot non Metric Multidimensional Scaling (nMDS) plankton pada waktu musim penangkapan ikan penja adalah

Gambar 10 menunjukkan perbedaan hasil struktur komunitas plankton antar waktu penangkapan ikan penja. Struktur komunitas plankton pada saat musim penangkapan menunjukkan adanya titik-titik sampel yang mewakili kondisi di alam pada plot nMDS menunjukkan persebaran titik yang sama di setiap waktu penangkapan. Nilai stress nMDS plot plankton pada waktu penangkapan ikan penja sebesar 0,2 berdasarkan nilai stress yang lebih besar dari 0,2 menggambarkan plot kurang baik untuk digunakan. Terdapat empat nilai stress value yang digunakan untuk menilai akurasi dan tingkat kesalahan suatu plot dalam menggambarkan komposisi spesies yang sebenarnya di alam dengan struktur komposisi sampel yang diperoleh yaitu stress value $<0,05$ merupakan plot yang sempurna, dengan kemungkinan tidak ada kesalahan dalam menginterpretasikannya. Stress value $<0,15$ menggambarkan plot yang cukup akurat dengan tingkat kesalahan interpretasi rendah. Stress value $<0,2$ menggambarkan plot kurang baik untuk digunakan stress value $>0,2$ menggambarkan sangat besar kemungkinan terjadinya kesalahan menginterpretasikannya (Clarke 1993).

\section{Analysis Of Similarity (ANOSIM) Pada Waktu Musim Penangkapan Ikan Penja}

Hasil uji ANOSIM plankton pada waktu musim penangkapan ikan penja disajikan pada Tabel 2. Pada Tabel 2 menunjukkan ringkasan hasil analisis multivarians Anosim - Simper (PRIMER) pada waktu musim penangkapan ikan penja. Jika pada plot nMDS tidak terlalu memiliki 


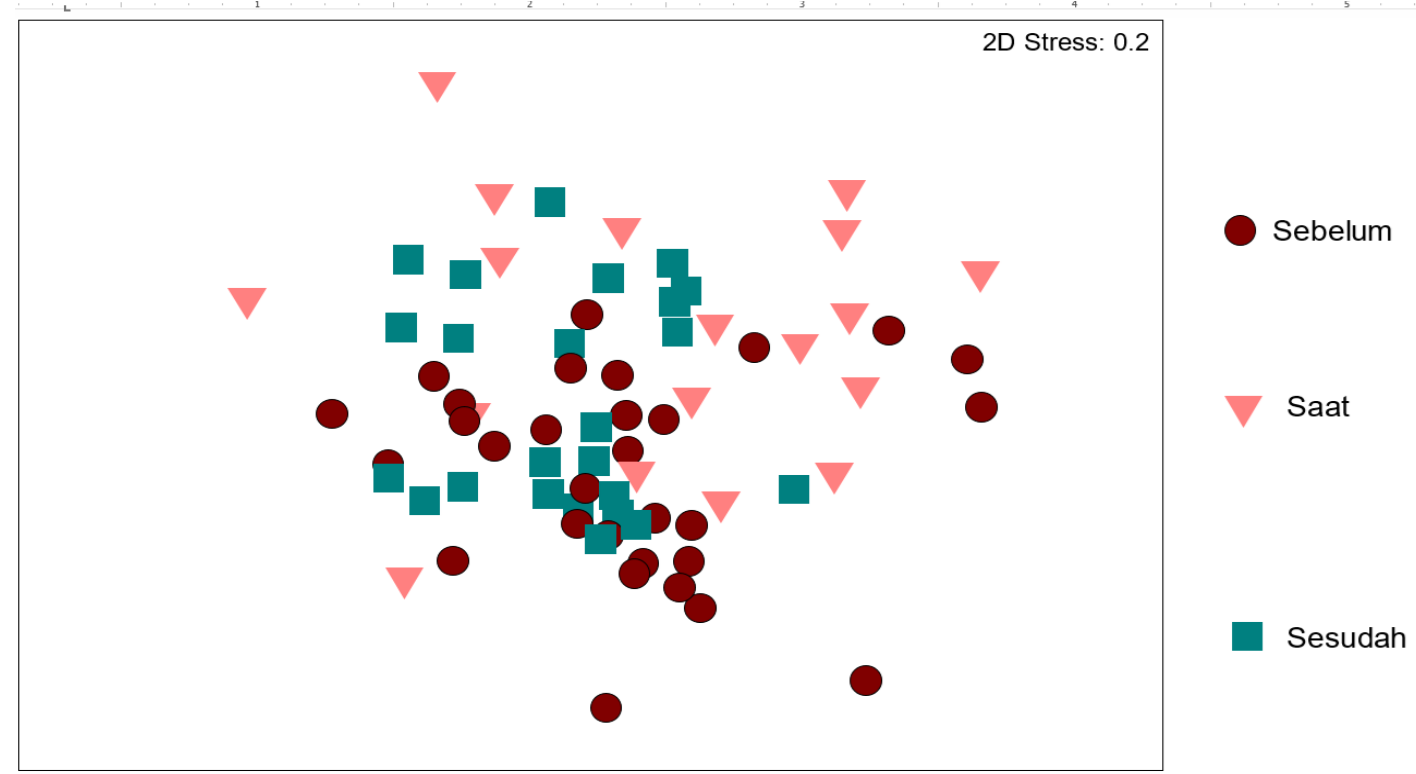

Gambar 10 Plot non Metric Multidimensional Scaling (nMDS) plankton pada waktu penangkapan ikan penja

Tabel 2 Ringkasan hasil analisis multivarians (PRIMER) pada waktu musim penangkapan ikan penja

\begin{tabular}{|c|c|c|c|c|}
\hline \multirow{2}{*}{ Pair wise } & \multicolumn{2}{|c|}{ Hasil ANOSIM } & \multirow{2}{*}{ Dissimilarty (\%) } & \multirow{2}{*}{$\begin{array}{l}3 \text { Spesies yang berkontri- } \\
\text { busi terhadap perbedaan }\end{array}$} \\
\hline & Global R & Tingkat Perbedaan & & \\
\hline \multicolumn{5}{|c|}{ Antar Waktu Penangkapan } \\
\hline Sebelum vs saat & 0,258 & 0,001 & 58,67 & $\begin{array}{l}\text { Copepoda }(8,35 \%), \\
\text { Asterionella }(8,23 \%), \\
\text { Tintinopsis }(5,91 \%) \text {. }\end{array}$ \\
\hline Sebelum vs Sesudah & 0,039 & 0,087 & 53,35 & $\begin{array}{l}\text { Tintinopsis }(8,05 \%) \text {, } \\
\text { Brachiounus }(6,89 \%) \text {, } \\
\text { Asterionella }(6,89 \%) \text {. }\end{array}$ \\
\hline Saat vs Sesudah & 0,239 & 0,001 & 54,47 & $\begin{array}{l}\text { Asterionella }(7,80 \% \text {, } \\
\text { Copepoda }(6,94 \%) \text {, } \\
\text { Tintinopsis }(6,60 \%) \text {. }\end{array}$ \\
\hline
\end{tabular}

perbedaan pada setiap waktu penangkapan ikan penja, begitu pula pada uji statistik. Setiap waktu musim penangkapan ikan penja memiliki tingkat perbedaan yang sangat kecil. Pada waktu sebelum dengan saat penangkapan ikan penja struktur komunitas berbeda nyata dengan nilai perbedaan yaitu $0,1 \%$ dan sepsies yang sangat berkontribusi dalam perbedaan pada waktu sebelum dan saat penangkapan yaitu Copepoda (8,35\%), Asterionella (8,23\%), dan Tintinopsis sp (5,91\%). Kemudian pada waktu sebelum dengan sesudah penangkapan ikan struktur komunitas tidak berbeda nyata dengan nilai perbedanya yaitu $8,7 \%$ dan sepsies yang sangat berkontribusi dalam perbedaan pada waktu sebelum dan sesudah penangkapan yaitu Tintinopsis $(8,05 \%)$, Brachiounus (6,89\%), dan Asterionella (6,89\%). Sedangkan Pada waktu saat dengan sesudah penangkapan ikan penja struktur komunitas berbeda nyata dengan nilai perbedaan yaitu $0,1 \%$ dan sepsies yang sangat berkontribusi dalam perbedaan pada waktu saat dan sesudah penangkapan yaitu Asterionella $(7,80 \%$, Copepoda (6,94\%), dan Tintinopsis $(6,60 \%)$. Tingkat perbedaan pada setiap waktu penangkapan ikan penja menunjukkan $\mathrm{P}<0,05$ maka pada waktu sebelum dengan saat dan saat dengan sesudah penangkapan memiliki struktur komunitas plankton yang berbeda nyata dan waktu sebelum dengan sesudah penangkapan ikan penja menunjukkan nila $\mathrm{P}>0,05$ maka pada waktu sebelum dengan sesudah tidak memiliki struktur komunitas plankton yang berbeda nyata.

\section{non Metric Multidimensional Scaling (nMDS) Bulan Penelitian}

Plot non Metric Multidimensional Scaling (nMDS) plankton bulan penelitian berdasarkan Gambar 11 menunjukkan perbedaan hasil struktur komunitas plankton pada bulan November dan Desember. Terdapat perbedaan struktur komunitas plankton berdasarkan bulan penelitian diamana komunitas plankton lebih tinggi ditemukan pada bulan Desember, hal ini 
menunjukkan adanya pengelompokkan jenis plankton yang melimpah pada bulan tersebut, karena adanya kandungan nutrient yang cukup tinggi pada bulan Desember karena merupakan puncak musim hujan dimana aliran nutrien terbawa oleh aliran air sungai.

\section{Analysis Of Similarity (ANOSIM) Pada Bulan Penelitian}

Hasil uji ANOSIM plankton pada bulan sampling disajikan pada Tabel 3. Berdasarkan Tabel 3 menunjukkan ringkasan hasil analisis multivarians Anosim - Simper (PRIMER) di November dan Desember. Pengambilan sampel pada bulan November dan Desember memiliki dissimilarity $54,44 \%$ dan tingkat perbedaan $2,7 \%$ atau 0,027 yang berarti berbeda nyata dimana $\mathrm{P}<0,05$ maka pada bulan November dan Desember memiliki struktur komunitas plankton yang berbeda nyata. Hal ini dikarenakan perbedaan kandungan nutrien fosfat pada bulan penelitan. Pada bulan November kandungan fosfat 0,18 dan 0,26 dan pada bulan Desember kandungan fosfat 0,26 dan 0,29. Kandungan fosfat yang optimum bagi pertumbuhan fitoplankton berkisar $0,27-5,51 \mathrm{mg} / \mathrm{L}$ (Hutabarat et al. 2013). Dan pengambilan sampel pada bulan penelitian ini mempunyai 3 spesies yang berkontribusi yaitu Asterionella (8,13\%), Tintinopsis (7,13\%), dan Brachionus (6,45\%). Di bulan November dengan Desember memiliki variasi sampel uji kecil. non Metric Multidimensional Scaling (nMDS) Pada Lokasi Pengambilan Sampel

Plot non Metric Multidimensional Scajling (nMDS) plankton pada lokasi lokasi sampling dapat dilihat pada Gambar 12. Menunjukkan adanya titik plot yang jelas pada muara, hal ini menggambarkan bahwa struktur komunitas plankton yang lebih tinggi pada muara dibandingkan pada aliran sungai. Sebagaimana sudah dijelaskan bahwa di muara kandungan unsur haranya lebih tinggi karena umumnya mendapatkan masukan nutrien yang lebih tinggi dari aliran sungai, maka nutrien tersebut dimanfaatkan oleh fitoplankton untuk tumbuh dan berkembang (Andriani et al. 2015).

Tabel 4 menunjukkan ringkasan hasil analisis multivarians Anosim - Simper (PRIMER) di muara dan sungai. Jika pada plot nMDS tidak terlalu memiliki perbedaan di setiap lokasi, begitu pula pada uji statistik, akan tetapi pada uji statistik antar muara dan badan sungai memiliki struktur komunitas yang berbeda nyata. Di muara dan sungai memiliki tingkat perbedaan spesies $0,1 \%$ atau 0,001 dengan spesies yang berkontribusi dalam perbedaan yaitu A sterionella (7,63\%), Tintinopsis (7,58\%), dan Nitzchia $(6,40 \%)$. Hal ini berarti bahwa spesies yang menjadi pembeda utama struktur komunitas plankton antar muara dan sungai yaitu Asterionella sp. Secara uji statistic, struktur komunitas antar muara dan sungai berbeda nyata karena nilai $\mathrm{P}<0,05$.

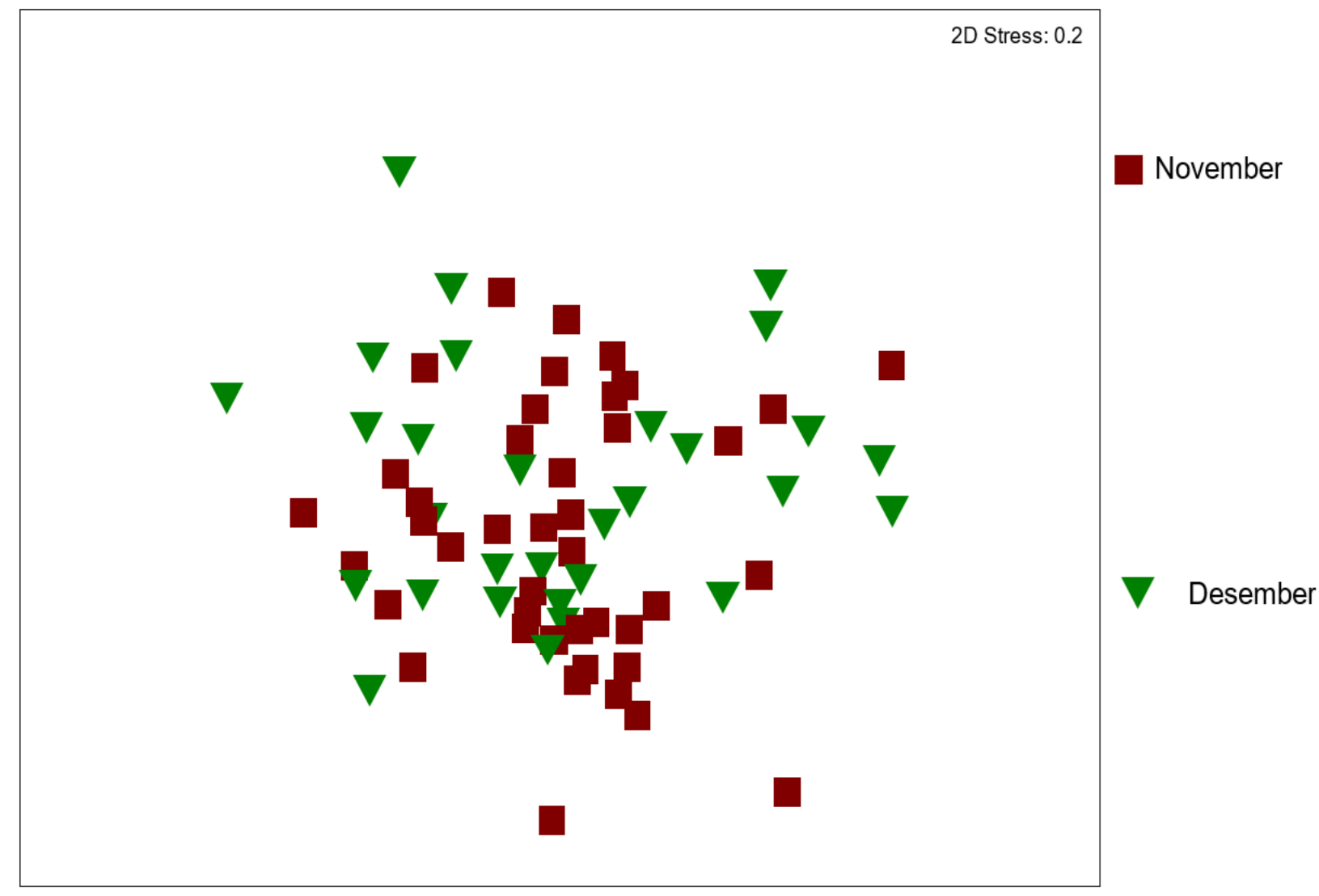

Gambar 11 Plot non Metric Multidimensional Scaling (nMDS) plankton pada waktu penelitian 


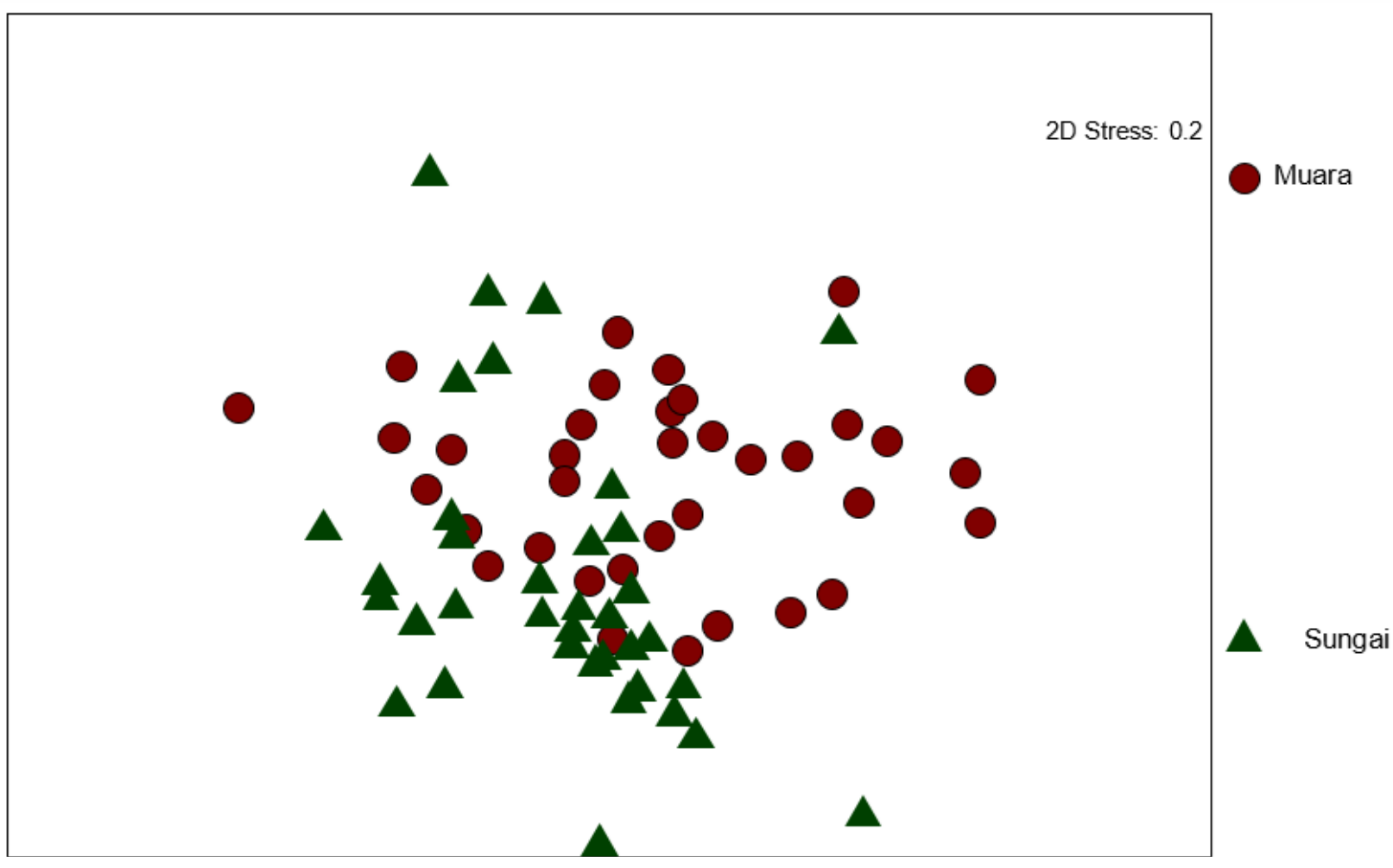

Gambar 12 Plot non Metric Multidimensional Scaling (nMDS) plankton pada lokasi sampling

Tabel 3 Ringkasan hasil analisis multivarians (PRIMER) pada bulan penelitian

\begin{tabular}{|c|c|c|c|c|}
\hline \multirow[b]{2}{*}{ Pair wise } & \multicolumn{2}{|c|}{ Hasil ANOSIM } & \multirow[b]{2}{*}{$\begin{array}{l}\text { Dissimilarty } \\
\qquad(\%)\end{array}$} & \multirow[b]{2}{*}{$\begin{array}{l}3 \text { Spesies yang berkontribusi } \\
\text { terhadap perbedaan }\end{array}$} \\
\hline & Global R & $\begin{array}{c}\text { Tingkat } \\
\text { Perbedaan }\end{array}$ & & \\
\hline \multicolumn{5}{|c|}{ Antar Waktu Penangkapan } \\
\hline $\begin{array}{l}\text { November vs } \\
\text { Desember }\end{array}$ & 0,067 & 0,027 & 54,44 & $\begin{array}{c}\text { Asterionella }(8,13 \%), \\
\text { Tintinopsis }(7,13 \%), \\
\text { Brachionus }(6,45 \%) .\end{array}$ \\
\hline
\end{tabular}

Tabel 4 Ringkasan hasil analisis multivarians (PRIMER) pada lokasi sampling

\begin{tabular}{ccccc}
\hline \multirow{2}{*}{ Pair wise } & \multicolumn{2}{c}{ Hasil ANOSIM } & Dissimilarty (\%) & $\begin{array}{c}\text { 3 Spesies yang ber- } \\
\text { kontribusi terhadap } \\
\text { perbedaan }\end{array}$ \\
\cline { 2 - 4 } & Global R & Tingkat Perbedaan & Antar Waktu Penangkapan \\
\hline $\begin{array}{c}\text { Muara vs } \\
\text { sungai }\end{array}$ & 0,16 & 0,001 & 57,02 & $\begin{array}{c}\text { Asterionella }(7,63 \%), \\
\text { Tintinopsis }(7,58 \%), \\
\text { Nitzchia }(6,40 \%) .\end{array}$ \\
\hline
\end{tabular}

\section{Parameter Kualitas air}

Suhu merupakan salah satu parameter yang penting bagi kelangsungan hidup organisme air, khususnya bagi organisme planktonik. Hasil pengukuran suhu berkisar antara $28-30{ }^{\circ} \mathrm{C}$. Suhu perairan dapat dikatakan baik bagi kelangsungan hidup organisme perairan karena masih sesuai dengan baku mutu air yakni $28-30^{\circ} \mathrm{C}$. kisaran suhu yang optimal bagi pertumbuhan plankton sekitar $20-30^{\circ} \mathrm{C}$ (Effendi 2003).

Salinitas juga berpengaruh bagi kelangsungan hidup organisme air. Secara keseluruhan rataan salinitas yang di dapat pada seluruh stasiun cukup baik yaitu berkisar 8-24\%o. menurut Nontji (2008), pada umumnya kisaran salinitas yang baik untuk kehidupan plankton adalah 11-40 \%. Menurut Nontji (1993), sebaran salinitas dalam perairan dapat dipengaruhi oleh beberapa faktor, seperti sirkulasi air, penguapan (evaporasi), curah hujan dan aliran sungai yang ada disekitarnya. Hasil pengukuran parameter kualitas air tertera pada Tabel 5. 
Tabel 5 Nilai Kisaran Parameter Fisika-Kimia yang diperoleh selama penelitian di muara dan aliran sungai Mandar

\begin{tabular}{|c|c|c|c|c|c|c|c|c|c|}
\hline \multirow{2}{*}{$\begin{array}{c}\text { Bulan } \\
\text { Penelitian }\end{array}$} & \multirow{2}{*}{ Lokasi } & \multirow{2}{*}{ Stasiun } & \multicolumn{7}{|c|}{ Parameter Fisika-Kimia } \\
\hline & & & Suhu & Salinitas & $\mathrm{pH}$ & Do & NO3 & PO4 & NH3 \\
\hline \multirow{6}{*}{ November } & \multirow{3}{*}{ Sungai } & 1 & $28-30$ & 0 & 8 & \multirow{3}{*}{5,44} & \multirow{3}{*}{1,705} & \multirow{3}{*}{0,1806} & \multirow{3}{*}{0,2679} \\
\hline & & 2 & & 0 & 8 & & & & \\
\hline & & 3 & & 0 & 8 & & & & \\
\hline & \multirow{3}{*}{ Muara } & 4 & $29-32$ & 8 & 8 & \multirow{3}{*}{4,80} & \multirow{3}{*}{0,1438} & \multirow{3}{*}{0,2647} & \multirow{3}{*}{0,1909} \\
\hline & & 5 & & 16 & 8 & & & & \\
\hline & & 6 & & 22 & 8 & & & & \\
\hline \multirow{6}{*}{ Desember } & \multirow{3}{*}{ Sungai } & 1 & $28-30$ & 0 & 8 & \multirow{3}{*}{5,12} & \multirow{3}{*}{0,7226} & \multirow{3}{*}{0,2682} & \multirow{3}{*}{0,6990} \\
\hline & & 2 & & 0 & 8 & & & & \\
\hline & & 3 & & 0 & 8 & & & & \\
\hline & \multirow{3}{*}{ Muara } & 4 & $28-31$ & 12 & 8 & \multirow{3}{*}{6,40} & \multirow{3}{*}{0,7322} & \multirow{3}{*}{0,2922} & \multirow{3}{*}{0,6260} \\
\hline & & 5 & & 18 & 8 & & & & \\
\hline & & 6 & & 24 & 8 & & & & \\
\hline
\end{tabular}

Hasil pengukuran $\mathrm{pH}$ di muara dan aliran sungai Mandar berkisar antara 7-8. Derajat keasaman perairan ini dapat dikatakan baik untuk pertumbuhan organisme air, sebagaimana Banerjea (1975) bahwa nilai $\mathrm{pH}$ suatu perairan antara 5,5-6,8 termasuk tidak produktif, kisaran 6,5 - 7,5 termasuk produktif dan kisaran 7,5 - 8,5 mempunyai produktifitas yang tinggi, sehingga kondisi $\mathrm{pH}$ sesuai bagi produktifitas plankton di lokasi perairan tersebut.

Oksigen $\left(\mathrm{O}_{2}\right)$ terlarut merupakan faktor pembatas bagi kehidupan makhluk hidup dalam perairan seperti plankton. Kandungan $\mathrm{O}_{2}$ di muara dan aliran sungai Mandar berkisar antara 4,8-6,8 ppm. Ini menunjukkan bahwa perairan tersebut kandungan oksigennya masih tergolong mendukung kehidupan organisme perairan, sebagaimana Effendi (2000) bahwa jika tidak terdapat senyawa toksik dalam perairan, maka kandungan $\mathrm{O}_{2}$ minimum dalam perairan sebesar 2 $\mathrm{mg} / \mathrm{l}$ sudah cukup mendukung kehidupan organism perairan secara normal. Selanjutnya Kristanto (2004) mengemukakan bahwa kehidupan dalam air dapat bertahan jika ada $\mathrm{O} 2$ terlarut minimum sebanyak $6 \mathrm{mg} / \mathrm{l}$, selebihnya tergantung kepada ketahanan organism, derajat keaktifannya, kehadiran pencemar, suhu air dan sebagainya. Oksigen dapat menjadi faktor pembatas dalam penentuan kehadiran organisme air.

Kandungan nitrat yang terukur berkisar 0,1 $0,8 \mathrm{ppm}$. Kisaran nitrat yang didapatkan tersebut cukup untuk mendukung perkembangan fitoplankton, sebagaimana yang dikatakan oleh Dirjen Perikanan (1985) bahwa kandungan nitrat yang dibutuhkan untuk perkembangan alga dan fitoplankton berkisar antara 0,3-17 mg/l. Nitrat dan fosfat merupakan nutrisi yang paling penting bagi pertumbuhan plankton (Nybakken 1992). Fosfat merupakan unsure penting dalam air. Fosfat terutama berasal dari sedimen yang selanjutnya akan terfiltrasi dalam air tanah dan akhirnya masuk ke system perairan (Barus 2004). Fosfat juga sangat bermanfaat untuk pertumbuhan organisme dalam air. Hasil pengukuran fosfat di perairan Muara dan badan Sungai Mandar berkisar 0,1-0,3 ppm. Suatu periaran dapat dikatakan subur apabila kadar fosfatnya berkisar antara 0,060-10 ppm (Effendi 2003).

\section{KESIMPULAN}

Komposisi jenis plankton yang ditemukan selama pengamatan, yakni: sebelum musim penangkapan, saat musim penangkapan dan setelah musim penangapan ikan penja di muara dan sungai Polman terdiri dari 37 genus plankton. Plankton dari kelas Bacillariophyceae paling dominan ditemukan yakni 11 spesies. Kelimpahan plankton terendah didapatkan setelah musim penangkapan. Untuk lokasi sampling kelimpahan tertinggi di temukan di muara pada bulan November. Kisaran nilai indeks keanekaragaman berdasarkan waktu penangkapan ikan penja, lokasi sampling dan waktu sampling adalah $1<\mathrm{H}^{\prime}<3$ yang berarti keanekaragaman sedang, nilai indeks keseragaman adalah 0,7-0,9 sehingga indeks keseragaman planktonnya adalah relatif sama atau merata, dan nilai indeks dominasi menunjukkan tidak ada genus dominan dalam komunitas.

\section{DAFTAR PUSTAKA}

Adiba IW. 2010. Struktur komunitas dan 
kelimpahan fitoplankton di Perairan Muara Sungai Porong Sidoarjo. Jurnal Kelautan. 3:37 -40 .

Andriani S, Tri RS, Irwan L. 2015. Kelimpahan dan sebaran horizontal fitoplankton di Perairan Muara Sungai Kakap Kabupaten Kubu Raya. Jurnal Protobiont. 4(1): 29-37.

APHA (American Public Health Association), 1989. Standar Methods for the Examination of Water and Waste. 17 th Edition, APHA (American Public Health Association). AWWA (American Waste Water Association). WPWC (Water Pollution Control Federation). Washington D.C.

Arsil MS. 1999. Struktur komunitas fitoplankton di Perairan Utara Pulau Batam Bintar dan Perairan Laut Natuna [skripsi]. Bogor (ID): Institut Pertanian Bogor.

Barus T. 2004. Pengantar Limnologi Studi Tentang Ekosistem Air Daratan. Medan (ID): USU Press.

Clarke KR. 1993. Non-parametric multivariate analyses of changes in commmunity structure. Austral Ecology. 18(1):117-143.

Clarke KR, Ainsworth M. 1993. A method of linking multivariate community structure to environmental variables. Mar. ecology progress series mar. Ecol. Prog. Ser. 92:205219.

Clarke KR, Gorley RN. 2001. PRMER V.5. User Manual Tutorial. Plymouth (UK): PRIMERE Ltd.

Dirjen Perikanan. 1985. Pedoman Budidaya Tambak. Jakarta (ID): Direktorat Perikanan Kementrian Kelautan dan Perikanan.

Effendi H. 2000. Telaah Kualitas Air Bagi Pengelolaan Sumberdaya dan Lingkungan Perairan. Yogyakarta (ID): Kanisius.

Effendi H. 2003. Telaah Kualitas A ir. Yogyakarta (ID): Kanisius.

Hasanah AN, Rukminasari N, Sitepu FG. 2014. Perbandingan kelimpahan dan struktur komunitas zooplankton di Pulau Kodingareng dan Lanyukang, Kota Makassar. Torani (Jurnal Ilmu Kelautan dan Perikanan). 24 (1):1-14.

Hutabarat S, Prijadi S, Ina C. 2013. Studi analisa plankton untuk menentukan tingkat pencemaran di Muara Sungai Babon Semarang. Management of Aquatic Resources Journal (MAQUARES). 2(3):7484.

Kristanto A. 2004. Komposisi jenis dan Kelimpahan zooplankton di perairan sungai Tallo Kotamadya Makassar [skripsi]. Makassar: Universitas Hasanuddin.

Newell GE, Newell R. 1977. Marine Plankton a Practical Guide $5^{\text {th }}$ Edition. London (UK): Unwin Hyman.

Nontji A. 1993. Laut Nusantara. Jakarta (ID):
Djambatan.

Nontji A. 2008. Plankton Laut. Jakarta (ID): LIPI Press.

Nybakken JW. 1992. Biologi Laut, Suatu Pendekatan Ekologi. Di terjemahkan oleh Eidman et. al. Jakarta (ID): PT. Gramedia.

Masson CF. 1981. Biologi of Fresh Water Pollution. New York (US): Longman Inc.

Odum EP.1971. Fundamental of Ecology. Georgia (US): University of Georgia.

Odum EP. 1993. Dasar-dasar Ekologi. Yogyakarta (ID): Gajah Mada University Press.

Radiarta N. 2012. Hubungan antara distribusi fitoplankton dengan kualitas perairan di Selat Alas Kabupaten Sumbawa Nusa Tenggara Barat. Jurnal Bumi Lestari. 13(2):234-244.

Sachlan M. 1972. Planktonology. Jakarta (ID): Correspondence Course Center.

Sudirman, Musbir, Fachrul. 2015. Kajian identifikasi, pola distribusi dan diversifikasi olahan ikan penja di Perairan Wilayah Sulawesi Barat [Laporan Hasil Penelitian]. Sulawesi Barat (ID): Badan Perencanaan Pembangunan Penelitian dan Pembangunan daerah Sulawesi Barat.

Soeroto B. 1988. Makanan dan reproduksi ikan payangka (Ophieleotris aporos) (Bleeker) di Danau Tondano [tesis]. Bogor (ID): Institut Pertanian Bogor.

Yamaji, 1960. Identification of Marine Plankton. Ilustsation of Marine Plankton of Japan. Osaka (JP): Hoikusha Publishing co.Itd. 